УДК 339.9;339.1

DOI: https://doi.org/10.26642/jen-2019-4(90)-222-229
О.О. Котенко, к.е.н., ст. викладач М.Д. Домашенко, к.е.н., доц. Сумський державний університет

С.В. Сердюк, експерт автомобільного ринку, стариий консультант з продажу автомобілів ПрАТ «Суми-Авто» «Автоиентр на Харківській»

\title{
Вплив міжнародного ринку електромобілів на розвиток інфраструктури доріг ${ }^{1}$
}

Одним зі значущчих питань бюджетної сфери України є бюджетні видатки на розбудову та відновлення інфраструктури доріг. Розвиток міжнародного ринку автомобілів та його всезростаючий вплив на економіку Украӥни може стати потужним поштовхом для вирішення питання в иій сфері. В изому випадку мова йде про ринок електромобілів та можливі шляхи створення системи оподаткування їх власників, щэо дозволить створити додаткове джерело поповнення державного бюджету України $i$ подальшого фінансування розвитку інфраструктури доріг.

Стаття присвячена обтрунтуванню дочільності та можливих шляхів створення $i$ впровадження в Украӥні специифічного непрямого податку, який би стягувався із власників електромобілів з метою акумулювання додаткових фінансових ресурсів для будівництва нової та відновлення існуючої інфраструктури доріг. У статті особливу увагу приділено соиіальній справедливості процесу введення такого податку в цілому, наведено найбільш реалістичні методи його стягнення, проаналізовано їх переваги та недоліки. Запропоновано варіанти щодо вибору бази оподаткування при розробці дорожнього збору з власників електромобілів, які трунтуються на: ринковій вартості електромобіля, вартості фактично спожитої електричноі енергії, страховій вартості електромобіля, експертній оцінці, використання спеціалізованого обладнання обліку спожитої електромобілем електричної енергії. Виявлено, щзо найбільш очевидним тактичним ріменням є покладення функцій щодо організації сплати дорожнього збору власниками електромобілів на страхові компанії. В якості стратегічного вирішення даноі проблеми запропоновано вважати побудову двосторонніх відносин між Урядом Украӥни та автовиробниками електромобілів з приводу розробки та впровадження спеціалізованого обладнання обліку спожитої електромобілем електричної енергії. Проведено розрахунок обсягу акцизу, який у рік сплачує в Україні середньостатистичний власник автомобіля із бензиновим двигуном та запропоновано механізм стягнення дорожнього збору з власників електромобілів.

Ключові слова: електромобілі; дорожній збір; державний бюджет; податки; енергоефективні технології; сталий розвиток; міжнародний ринок електромобілів.

Актуальність теми. Проблема пошуку шляхів диверсифікації ресурсної бази для поповнення бюджету країни є однією із найгостріших питань фінансово-економічної системи будь-якого рівня розвитку. Навіть у Сполучених Штатах Америки фіскальні органи систематично розробляють нові механізми та інструменти оподаткування для підтримання традиційного рівня соціального забезпечення. Інколи така практика часто призводить до появи досить дивних та, на перший погляд, нелогічних податків: податок на снігоходи, податок на чайові тощо. Разом з тим, такий досвід створює потужну ресурсну базу, яку вочевидь неможливо було б акумулювати іншим чином.

Наповнення державного бюджету та подолання дефіциту фінансування окремих напрямків фінансово-господарської є надзвичайно гострою проблемою і для України. Проте, з впевненістю можна стверджувати, українська податкова система, як і підприємництво, не готові до різкого збільшення кількості податків, а тому практика США може бути корисною більше як орієнтир, а не як конкретний дороговказ фіскального регулювання.

На жаль, сьогодні з-поміж всього комплексу питань, пов'язаних із бюджетними видатками, одне із них займає особливе місце - це збільшення фінансування потреб розбудови та відновлення інфраструктури доріг.

\footnotetext{
1 Робота виконувалася за рахунок бюджетних коштів МОН України, наданих на виконання науково-дослідної роботи № 0118U003571 «Інноваційний менеджмент енергоефективних та ресурсозберігаючих технологій в Україні» та № $0117 \mathrm{U} 003922$ «Інноваційні драйвери національної економічної безпеки: структурне моделювання та прогнозування»
} 
На нашу думку, одним із осередків покращення ситуації в цій галузі може стати бурхливий розвиток міжнародного ринку автомобілів та його все зростаючий вплив на економіку України. В даному випадку мова йде про ринок електромобілів та можливі шляхи створення системи оподаткування їх власників. Така практика, на наше переконання, створить певну синергію - безумовний позитивний ефект від енергозберігаючих технологій як таких (якими, зокрема, є і електромобілі), а також створення системи відповідних податків, надходження від яких могли б стати потужним додатковим джерелом поповнення державного бюджету України і подальшого фінансування розвитку відповідних галузей (у випадку електромобілів - інфраструктуру доріг).

Аналіз останніх публікацій. Проблеми наповнення бюджету знаходять своє відображення у численних наукових працях. Значний вклад у науковий доробок у тематику розвитку ринку електромобілів здійснили: Щ.В. Аргун, Я.І. Глущенко, А.В. Гнатов, О.І. Відоменко, В.С. Гірін, І.В. Гірін, В.П. Кужель, I.А. Майбури, В.І. Островецький, Б.Я. Панасюк, В.М. Опаріна Я.В. Шевчук. Розробці проблематики енергозберігаючих технологій, аналізом їх ролі як в економіці в цілому, так і в бюджетній сфері зокрема, присвячені праці таких авторів: В.І. Абєлєшов, М.С. Барабаш, Л.Д. Богуславський, I.М. Бутовський, А.С. Горшков, О.Л. Підгорний, М.В. Савицький, О.Д. Самарін, Г.С. Ратушняк.

Метою статті є обгрунтування доцільності та можливих шляхів створення і впровадження в Україні специфічного непрямого податку на використання електромобілів як аналога акцизного збору, що стягується під час купівлі палива власниками автомобілів із традиційною силовою установкою, а також уточнення характеру впливу міжнародного ринку електромобілів на процес наповнення державного бюджету України.

Викладення основного матеріалу. Ринок енергозберігаючих технологій в Україні за останні роки розвивається семимильними кроками. Все більші обсяги альтернативних джерел енергії вводяться в експлуатацію (сонячні, вітрові електростанції, побутова енергонезалежність тощо), ефективно функціонують та слугують потужнім інструментом забезпечення сталого розвитку, в напрямку якого Україна взяла впевнений курс [2-4].

У більшості випадків, економічний ефект від впровадження альтернативних джерел енергії базуються на частковій або повній відмові від традиційних джерел, що, в свою чергу, дозволяє економити фінансові ресурси та вивільнити їх для потенційно більш доцільного використання [1]. 3 цієї точки зору, створення додаткового фінансового тягаря, у вигляді податків на енергозберігаючі технології $\epsilon$ певним покаранням фізичної особи чи підприємства, що їх фінансують та впроваджують, за те, що вони взагалі це роблять - за економію енергоносіїв. Вочевидь, така практика не має нічого спільного із соціальною справедливістю, загальмує на десятиліття будь-які проекти в сфері енергозбереження та поверне нашу державу до екстенсивних методів господарювання, чого допустити категорично не можна.

Проте, сфера електромобілів - зовсім інше питання. Заправляючи автомобіль на АЗС, власник автомобіля з класичною силовою установкою має сплатити зокрема акцизний збір та ПДВ. Чим частіше i довше автомобіль знаходиться в експлуатації - тим більший акцизний збір та ПДВ стягується 3 його власника: пряма залежність. Весь обсяг акцизних платежів від купівлі палива (бензинів або дизельного палива) надходить до державного бюджету і складає, зокрема, фінансову основу для розбудови та відновлення інфраструктури доріг.

Протилежна ситуація виникає у випадку електромобілів: для їх використання не існує необхідності купувати паливо, а відтак і сплачувати акциз та ПДВ. В даному випадку, якщо не заглиблюватися у подальший аналіз електромобілів можна зробити висновок аналогічний тому, який ми зробили для енергозберігаючих технологій в цілому. Разом з тим, якщо населення чи підприємства мають намір впроваджувати, скажімо, альтернативну енергетику, то вони це здійснюють або на площах, які належать їм безпосередньо, або які вони орендують. Іншими словами, для задоволення іх потреби у альтернативній енергетиці, інтереси третіх сторін не порушуються. Власники ж електромобілів аналогічно впливають на фізичне зношення інфраструктури доріг (як і власники автомобілів із класичною - паливною силовою установкою), не відшкодовуючи при цьому кошти в тому обсязі, як це роблять власники автомобілів із класичною силовою установкою.

На нашу думку, такий стан справ дещо порушує соціально-економічну справедливість у суспільстві та $є$ однією із причин недоотримання бюджетом певного (пропорційного використовуваній кількості електромобілів в країні) обсягу фінансування.

Більше того, проблема оцінки впливу електромобілів на фізичний знос дорожнього покриття посилюється тим, що технічні особливості (характеристики), за якими автомобільний транспорт провокує знос дорожнього покриття, ідентичні для електромобілів та автомобілів з ДВЗ. Наведемо приклад таких характеристик для легкового автомобіля Nissan Leaf [14]:

- вага у 1500-1600 кг, що є типовим середнім значенням для автомобіля аналогічних габаритів;

- динамічні характеристики: швидкість розгону до 100 км/год.: 10-11 секунд; максимальна швидкість: 145 км/год., що в цілому відповідає середнім показникам на ринку автомобілів 3 ДВ3 або обмеженням швидкісного режиму, прийнятим в Україні.

- стандартні характеристики гуми: розмір та склад. 
Звісно, електромобілі мають заряджатися, тому свою частку виплат до бюджету здійснюють у вигляді купівлі енергії, але за нашими підрахунками, якщо вартість одного кілометра шляху, пройденого електромобілем, залежить від умов, у 4-8 разів є нижча різниця у обсягах відшкодування є відчутною [6]. Більше того, якщо тариф за використання електроенергії сплачується енергогенеруючій компанії, яка спочатку формує дохід і лише потім сплачує податки, то акциз стягується напряму до бюджету.

На підтвердження, можна навести прості розрахунки (табл. 1).

Таблиия 1

Порівняння вартості 100 км пробігу електромобіля Nissan Leaf та усередненого (гіпотетичного) автомобіля із бензиновим двигуном

\begin{tabular}{|c|c|c|c|c|c|}
\hline Автомобіль & $\begin{array}{c}\text { Вид зарядки/ } \\
\text { заправки }\end{array}$ & $\begin{array}{c}\text { Витрата } \\
\text { енергоносія }\end{array}$ & Тариф, грн & $\begin{array}{c}\text { Вартість 100 } \\
\text { км шляху, грн }\end{array}$ & $\begin{array}{c}\text { Розмір } \\
\text { акцизу }\end{array}$ \\
\hline $\begin{array}{c}\text { Nissan Leaf } \\
\text { (електричний } \\
\text { двигун) }\end{array}$ & $\begin{array}{c}\text { Від побутової } \\
\text { мережі }\end{array}$ & 24 кВТ*г/100 км $^{*} 1,68 г р н / \kappa В T^{*} \Gamma$ & 40,32 & - \\
\hline $\begin{array}{c}\text { Інші } \\
\text { (бензиновий } \\
\text { двигун) }\end{array}$ & АЗС & 10 л/100 км & 30,79 грн/літр & 307,90 & $\begin{array}{c}5,64 \\
\text { грн/л }\end{array}$ \\
\hline
\end{tabular}

Довідка: розробка автора

Наведемо деякі пояснення до таблиці:

1. Nissan Leaf було обрано нам для аналізу як найбільш популярний електромобіль на українському ринку (за даними Асоціації «Укравтопром» за 9 місяців 2019 року частка продажу даного автомобіля складає більше за 46 \% від загальної кількості проданих електромобілів) [12];

2. Витрата енергоносія - це обсяг витраченого умовного енергоносія (бензину марки А-95 Євро та електроенергії). Для електромобіля дані взяті із оприлюднених офіційних технічних характеристик. Для бензинового автомобіля ми взяли приблизні усереднені дані щодо споживання палива.

3. Тарифи. Тариф 168 к. - вартість електричної енергії за умови споживання понад 100 кВт*г/місяць (з впевненістю можна стверджувати, що власники електромобілів, постійно заряджаючи їх дома, будуть споживати понад 100 кВт*г/місяць) [11]. Вартість бензину А-95 Євро була взята із офіційного сайту мережі АЗС «ОККО» [9].

4. Розмір акцизу відповідно до чинного Податкового кодексу України [10], акцизний збір за звичайні моторні бензини складає 213,5 Євро/1000 л. Відповідно, у перерахунку на 1 літр та за курсом НБУ [9] євро до гривні на 27.09.2019 р. (26,4 грн/євро), акциз на бензин складає 5,64 грн/л.

В межах даного дослідження, ми не беремо до уваги ті податки, які сплачують підприємства, залучені у процес вироблення бензину чи електроенергії.

Інше питання в цьому контексті - це діяльність комерційних станцій зарядки електромобілів, що диференціюють вартість своїх послуг в залежності від типу зарядки (швидкісна та звичайна). Однак, електроенергія для підприємств-власників таких станцій $\epsilon$ лише непідакцизним товаром. Іншими словами, до державного бюджету від власників мережі станцій зарядки йдуть лише податки, тоді як від АЗС - податки, ліцензійні збори та акцизи від власників авто з ДВЗ.

Саме в поєднанні наведених фактів ми вбачаємо той незначний фінансовий вклад, який здійснюють власники електромобілів у розвиток інфраструктури доріг.

На даному етапі дослідження розрахуємо приблизний обсяг акцизу, який у рік сплачує в Україні середньостатистичний власник автомобіля із бензиновим двигуном. 3 цією метою припустимо, що:

- в середньому один календарний рік включає 250 робочих днів;

- шлях від дому до роботи і назад у місті-мільйонері приймемо за 40 км, у середньому місті 10 км. Тобто в середньому - близько 25 км/день;

- $\quad$ середню витрату палива бензинового автомобіля приймемо за 10 л/100 км.

Таким чином, розрахуємо вартість акцизу, що сплачує середньостатистичний власник автомобіля із бензиновою силовою установкою:

$$
A=5,64 \frac{2 p H}{\pi} \times 0,1 \frac{\pi}{\kappa м} \times 25 \frac{\kappa M}{\partial е н ь} \times 250 p . \partial=3625 г p н / p i \kappa .
$$

Розрахувати хоча б наближені дані щодо того, який вклад у поповнення державного бюджету здійснюють власники електромобілів, за цим принципом доволі складно, оскільки неможливо оцінити частку їх платежів, що припадає на 1 грн сплачених податків енергогенеруючими компаніями в Україні. Разом з тим, та зважаючи на наведені вище дані, цю суму не можна вважати значною. 
Отриманим значенням середнього річного акцизного збору, що сплачуть власники автомобілів 3 ДВС, купуючи паливо, можна обкладати власників електромобілів у вигляді своєрідного дорожнього збору.

Очевидно, що таку експрес-оцінку потенційного дорожнього збору для електромобілів також не можна вважати абсолютно об’єктивною та соціально-справедливою, оскільки:

- купівля електромобіля не означає, що ним активно користуються або що ним взагалі користуються (власник все одно буде зобов'язаний його сплачувати);

- інтенсивність використання електромобіля також може бути різною: автомобілі окремих власників проходять 300 км/день; у інших - автомобіль більшість часу може взагалі не виїжджати;

- електромобіль може заряджатися на спеціальній станції, або в інших місцях із традиційних джерел живлення. Електроенергія для електромобіля може братися як із загальної мережі, так і генеруватися потужностями власника (зокрема, сонячними панелями). На нашу думку, це також має братися до уваги;

- акциз на бензин враховує інтенсивність використання автомобіля (за принципом: «більше придбаного палива - більше пройдених кілометрів»). Екстраполювати це на електрику, в сучасних умовах, доволі важко (якщо взагалі можливо).

На противагу цьому, можна зауважити, що купівля полісу ОСЦПВ є обов'язковим для отримання права використовувати автомобіль (його купівля або розмір плати не залежить від того, як інтенсивно використовується автомобіль). Таким чином, ОСЦПВ зобов'язані оплачувати всі власники автомобілів.

В даному контексті, необхідно акцентувати увагу на тому зв'язку, який існує між проблемою наповнення державного бюджету України: видатками із нього на потреби будівництва та відновлення інфраструктури доріг та міжнародним ринком електромобілів.

Кон'юнктура міжнародного ринку електромобілів сьогодні характеризується: а) розширенням переліку пропонованих моделей електричних легкових та вантажних автомобілів; б) розширення доступу до українського ринку вживаних електромобілів, кількість яких складає майже 3/4 3-поміж всього парку (91 \% проданих в Україні електромобілів за I-III квартали 2019 р. були у вжитку) [12]; в) існування можливості придбати вживаний автомобіль в розстрочку, що, зважаючи на сучасну практику банківського кредитування в нашій державі, є майже неможливим для ринку автомобілів із ДВЗ. Зростання «лояльності» світового ринку електромобілів через створення більш привабливих, у порівнянні із ринком автомобілів із ДВЗ, цінових пропозицій, зумовлює стрімке зростання попиту кількості зареєстрованих електромобілів в Україні, а тому і їх кількості. Ця ситуація поступово збільшує частку електромобілів в загальній структурі видів автотранспорту.

Відповідно, розроблення механізму оподаткування власників електромобілів, створення спеціальних тарифів - це лише питання часу. Більше того, у часи, коли електромобілі складатимуть більшу частку рухомого складу, це питання буде вирішуватися так, як сьогодні вирішується із власниками автомобілів із ДВС.

Досить важливим фактором в даному випадку $є$ відсутність національних виробників, які б пропонували на українському ринку легкові та вантажні автомобілі українського виробництва. Взаємодія із ринками електромобілів на сьогодні в Україні є міжнародними економічними відносинами.

Це означає, що в сучасних реаліях наповнення державного бюджету України від використання електромобілів залежить від:

- розробки соціально-справедливого механізму стягування певних зборів із власників електромобілів, еквівалентних акцизному збору, який стягується при купівлі палива;

- змін кон'юнктури на міжнародному ринку електромобілів: економічна політика нафтовидобувних компаній та автовиробників і характер їх інтересів на цільових ринках, фінансові можливості щодо кредитування купівлі електромобілів тощо.

Яким же чином можна організувати систему стягування дорожнього збору 3 власників електромобілів?

Перш за все, варто сказати про стан самого ринку електромобілів. 3 впевненістю можна стверджувати, що хоча ринок на сьогоднішній день в Україні активізується і з кожним роком кількість електромобілів, зареєстрованих в нашій державі, збільшується, він ще не готовий до такого удару. Крім того, держава намагається стимулювати ринок. Так, відповідно до пункту 64 підрозділу 2 розділу ХХ Податкового Кодексу України, до 31 січня 2022 р. автомобілі, оснащені електродвигуном звільняються від сплати ПДВ при ввезенні їх на митну територію нашої держави [10].

Але навіть в умовах підвищення лояльності внутрішнього ринку України та впровадження ряду митних та організаційних переваг (зміни до ДБН, відповідно із якими 5 \% місць на паркувальних майданчиках 331 липня 2019 р. мають відводитися для електромобілів [5]), більшість автовиробників, автомобільний ряд яких включає і електромобілі, лише роблять перші кроки щодо їх офіційного ввезення на територію нашої держави. Це можна пояснити рядом причин: 
- по-перше, високий рівень скепсису в нашій державі щодо купівлі електромобіля. Як правило, потенційні власники просто не знають всіх характеристик електромобілів, а значить не можуть оцінити всі їхні переваги [13];

- по-друге, вартість нового електромобіля, на жаль, на сьогодні значно перевищує вартість аналогів із ДВЗ (вартість найдешевшого нового електромобіля може перевищувати вартість класичного автомобіля майже вдвічі);

- по-третє, побоювання потенційних власників щодо вартості обслуговування акумуляторів;

- по-четверте, часто технічні характеристики електромобіля не можуть задовольнити потреби власника у пересуванні [7]. Часто електромобіль $є$ другим автомобілем у домогосподарстві.

Також необхідно опрацювати всі можливі варіанти стягування дорожнього збору 3 власників електромобілів. Змоделюємо ситуації та представимо нашу оцінку можливості впровадження того чи іншого варіанта (табл. 2).

Таблиця 2

Потенційні варіанти щзодо вибору бази оподаткування при розробиці дорожнього збору з власників електромобілів

\begin{tabular}{|c|c|c|c|c|}
\hline $\begin{array}{c}\text { № } \\
\text { 3/II }\end{array}$ & 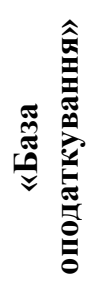 & 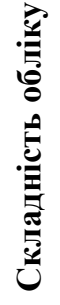 & 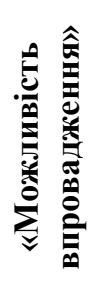 & «Коментар» \\
\hline 1 & 2 & 3 & 4 & 5 \\
\hline 1. & 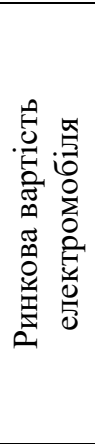 & 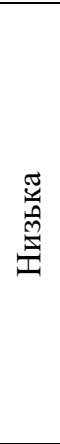 & 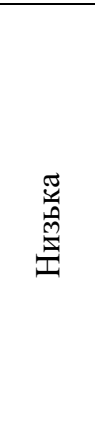 & $\begin{array}{l}\text { Певною ставкою дорожнього збору можна обкладати власників при } \\
\text { купівлі електромобіля, але це одразу стане додатковим } \\
\text { демотивуючим фактором розвитку ринку. Дорожній збір за таким } \\
\text { принципом буде стягуватися лише один раз - під час купівлі } \\
\text { електромобіля. } \\
\text { Крім того, з впевненістю можна стверджувати, що вартість автомобіля } \\
\text { (як і вартість електромобіля) не має жодного зв'язку із інтенсивністю } \\
\text { його використання власником. В результаті, більш дорогий } \\
\text { електромобіль, що використовується лише для побутових потреб, буде } \\
\text { обкладатися більшим дорожнім збором, ніж більш дешевий, який } \\
\text { активно використовується для потреб приватного бізнесу }\end{array}$ \\
\hline 2. & 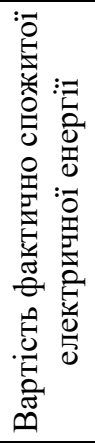 & 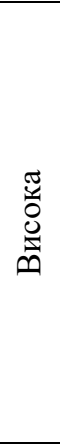 & 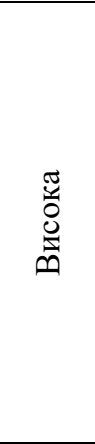 & $\begin{array}{l}\text { Теоретично, здійснити такий облік не складно: більший пробіг } \\
\text { електромобіля - більше необхідно сплатити. Складніше розробити } \\
\text { адекватний та соціально-справедливий механізм, за яким такий } \\
\text { облік буде здійснюватися. Електромобіль може заряджатися в } \\
\text { домогосподарстві, на підприємстві, з заряджаючих станцій, інших } \\
\text { джерел. Інше питання - як диференціювати електроенергію, яка } \\
\text { використовується електромобілем та на інші потреби. } \\
3 \text { іншого боку, якщо такий механізм буде створено, його досить } \\
\text { легко впровадити. } \\
\text { Але встановлення спеціального приладу незалежного обліку на всі } \\
\text { розетки та джерела енергії-економічний абсурд }\end{array}$ \\
\hline 3. & 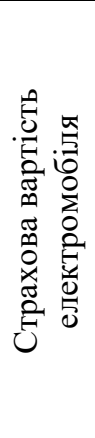 & 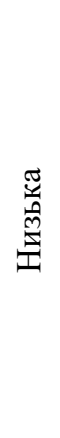 & 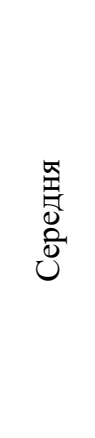 & $\begin{array}{l}\text { Може бути організована у вигляді щорічної одноразової сплати } \\
\text { дорожнього збору при оформленні поліса ОСЦПВ. Це зручно і } \\
\text { легко для обліку. Разом з тим, вартість самого поліса ОСЦПВ, як } \\
\text { правило, не значна порівняно із акцизами, що сплачуються під час } \\
\text { купівлі палива. Тому відсоток від вартості полісу не є достатньою } \\
\text { базою для дорожнього збору. Звісно, що замість вартості поліса } \\
\text { ОСЦПВ, при розрахунку дорожнього збору для електромобілів } \\
\text { можна було б використовувати вартість поліса КАСКО, що в } \\
\text { десятки разів може перевищувати вартість поліса ОСЦПВ, але } \\
\text { КАСКО в Україні не є обов'язковим, тому його використання у } \\
\text { вигляді бази для розрахунку, не є можливим }\end{array}$ \\
\hline
\end{tabular}


Закінчення табл. 2

\begin{tabular}{|c|c|c|c|c|}
\hline 1 & 2 & 3 & 4 & 5 \\
\hline 4. & 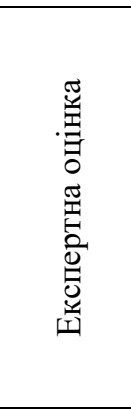 & 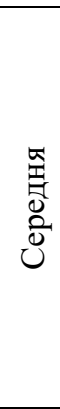 & 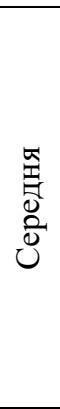 & 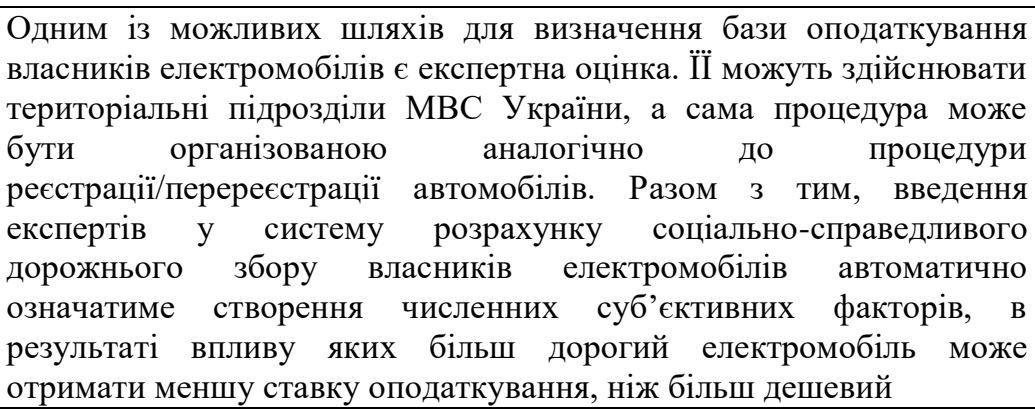 \\
\hline 5. & 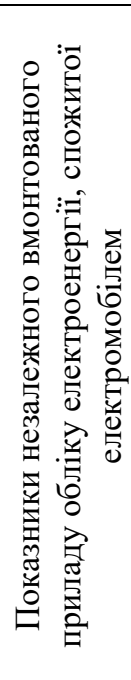 & 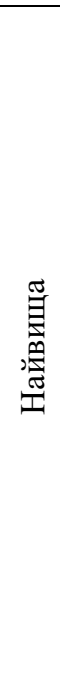 & 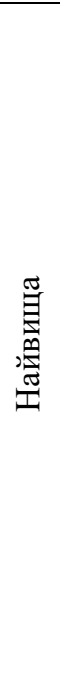 & 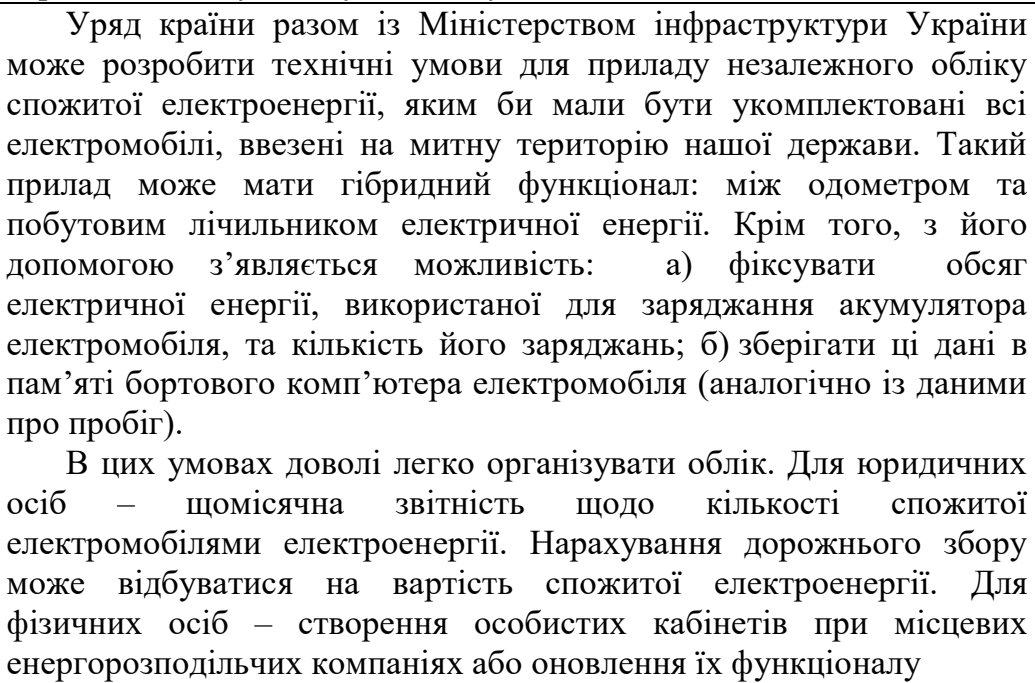 \\
\hline
\end{tabular}

Як резюме до таблиці 2 можна сказати, що сьогодні та у найближчому майбутньому найбільш очевидним рішенням, на нашу думку, є покладення функцій щодо організації сплати дорожнього збору власниками електромобілів на страхові компанії. Це зумовлюється такими чинниками:

1. Власники автомобілів (електромобілів) зобов'язані кожного року оплачувати поліс ОСЦПВ - це фактично єдина вимога держави до власників моторних транспортних засобів. Відтак, покладання такої функції на страхові компанії позбавить введення у систему певної третьої сторони. Тому такий принцип буде відносно простим, дешевим та прозорим;

2. При сучасному стані справ не існує жодного механізму (як і технологій) обліку витраченої електроенергії саме на потреби електромобілів домогосподарствами та бізнесом. Тому непрямий податок може стягуватися один раз на рік у вигляді єдиного стандартизованого платежу. За часом він буде збігатися із купівлею полісу ОСЦПВ.

3. Як зазначалося вище, власники автомобілів (електромобілів), які 3 різних причин не використовують свій транспорт взагалі, як правило, не оплачують поліс ОСЦПВ. У такому випадку, вони звільняються від дорожнього збору. Це можна вважати елементом соціальної справедливості.

Разом $з$ тим зазначимо, що це доволі швидке, але неідеальне рішення. Стратегічним вирішенням даної проблеми є лише тісна двостороння співпраця між Урядом України та автовиробниками з приводу створення спеціальних приладів обліку спожитої електромобілем електричної енергії. Створення такого механізму може бути доволі довгим процесом, спричинить певне підвищення ціни на електромобілі, вартість їх експлуатації (у порівнянні із сьогоденням) та створить незручності їх власникам. Разом 3 тим, така практика вбачається нам як така, що найкращим чином реалізує принцип соціальної справедливості, не входить в протиріччя із концепцією сталого розвитку та надає можливості отримання додаткових надходжень до державного бюджету.

Висновки та перспективи подальших досліджень. Енергоефективні технології - це те, без чого неможливо собі уявити забезпечення сталого розвитку людства. Зважаючи на загострення екологічних проблем, поступове підвищення вартості енергоносіїв (особливо викопного палива), підвищення еколого-економічної грамотності суспільства, можна стверджувати, що 3 кожним роком ми будемо ставати свідками того, як енергоефективні технології будуть все активніше проникати у повсякденне життя громадян. 
Міжнародний ринок електромобілів із його специфічною мінливою кон'юнктурою у співпраці із Урядом України може стимулювання громадян до поступової відмови від автомобілів із класичною силовою установкою на користь електричної тяги. Водночас цей процес не може бути стрімким, зважаючи на об’єктивні причини, та мати примусовий характер, а це значить, що ще певний час (можливо, що доволі довгий) двигуни внутрішнього згоряння залишатимуться доволі популярними на ринку.

Зважаючи на зростаючу вартість бензину та дизельного палива, збільшення кількості автомобілів, держава із року в рік буде отримувати все більші обсяги акцизних платежів від власників автомобілів із ДВ3, поповнюючи цим самим бюджет та направляючи кошти зокрема і на потреби будівництва та утримання доріг, чого електромобілі забезпечити сьогодні не можуть.

Ситуація докорінно зміниться тоді, коли частка електромобілів складатиме більшість, а тому поява податкових відносин між їх власниками та державою - це лише питання часу. Такі відносини у стратегічній перспективі, на нашу думку, мають бути реалізованими у вигляді: створення технічних умов для розробки автовиробниками незалежних приладів обліку спожитої електроенергії, якими б комплектувалися всі електромобілі, ввезені на митну територію України; процедур звітності власниками електромобілів щодо спожитої електричної енергії; механізмів нарахування дорожнього збору; системи штрафних санкцій за неправдиву інформацію, несвоєчасну звітність тощо. Розробці такого механізму будуть присвячені подальші наші дослідження.

Але вже зараз ми можемо сказати, що основою побудови такого роду відносин має бути виключно на соціальній справедливості, економічній доцільності та практичній значущості та бути орієнтованими на захист інтересів прийдешніх поколінь, що і $є$ основою концепції сталого розвитку людства.

\section{Список використаної літератури:}

1. Аргун Щ.В. Екологічний та енергоефективний електромобільний транспорт та його інфраструктура / Щ.В. Аргун, А.В. Гнатов, О.А. Ульянеи // Вісник ЖДТУ. - 2016. - № 2 (77). - С. 18-26.

2. Відоменко O.I. Перспективи розвитку електромобільного транспорту в Україні / O.I. Відоменко // Наукова думка : мат-ли Міжн. наук.-практ. конференції, 19 черв. 2017 р., Одеса. - Т. 4. - С. 50-54.

3. Гірін В.С. Сучасний стан електромобільного транспорту та його перспективи в Україні / В.C. Гірін, I.B. Гірін // Гірничий вісник. - 2017. - Вип. 102. - С. 21-26.

4. Грома Я.В. Порівняльний аналіз ринку електромобілів в Україні та світі / Я.В. Грома, Я.І. Глущенко [Електронний ресурс]. - Режим доступу : http://ev.fmm.kpi.ua/article/download/181408/181350.

5. 31 липня вступають у дію зміни в ДБН, які зобов'язують влаштовувати на парковках мінімум 5 \% місць 3 електрозарядками [Електронний ресурс]. - Режим доступу : https://www.kmu.gov.ua/news/z-1-lipnyavstupayut-v-diyu-zmini-v-dbn-yaki-zobovyazuyut-vlashtovuvati-na-parkovkah-minimum-5-misc-zelektrozaryadkami.

6. Котенко О.O. Енергоефективні автомобілі та їх роль в антикризовій стратегії підприємств України / О.О. Котенко, М.Д. Домашенко, С.В. Сердюк // Облік і фінанси. - 2019. - № 1 (83). - С. 152-158.

7. Кужель В.П. Проблеми та перспективи експлуатації електромобілів на території України / В.П. Кужель, O.B. Харчук // Збірник наукових праць науково-технічної конференції Вінницького національного технічного університет (фак.-т маш.-буд. та транс.), 10-11 березня 2016 р. / Вінницький національний технічний університет.

8. Офіційний курс гривні щодо іноземних валют на 27.09.2019 / Національний банк України [Електронний pecypc]. - Режим доступу : https://bank.gov.ua/markets/exchangerates?date=27.09.2019\& period=daily

9. Паливо Свро 5 [Електронний ресурс]. - Режим доступу : https://www.okko.ua/ru/fuels.

10. Податковий кодекс України : документ № 2755-VI : ред. від 20.10.2019 [Електронний ресурс]. - Режим доступу : https://zakon.rada.gov.ua/laws/show/2755-17.

11. Тарифи на електроенергію, що відпускається населенню [Електронний ресурс]. - Режим доступу : https://www.nerc.gov.ua/?id=15013.

12. Український ринок електромобілів набирає обертів, в тренді - секонд-хенд [Електронний ресурс]. - Режим доступу : http://ukrautoprom.com.ua/ukra\%d1\%97nskij-rinok-elektromobiliv-nabiraye-obertiv-v-trendi-sekond-xend.

13. Шевчук O.I. Перспективи експлуатації та конкурентна спроможність електромобілів в Україні / O.I. Шевчук // Науковий вісник Херсонського державного університету. - 2016. - Вип. 21, Ч. 2. - С. 43-46.

14. Nissan Leaf Specifications [Електронний ресурс]. - Режим доступу : https://www.nissanusa.com/vehicles/electric-cars/leaf.html.

\section{References:}

1. Argun, Shh.V., Gnatov, A.V. and Ul'janec, O.A. (2016), «Ekologichnyj ta energoefektyvnyj elektromobil'nyj transport ta jogo infrastruktura», Visnyk ZhDTU, No. 2 (77), pp. 18-26.

2. Vidomenko, O.I. (2017), «Perspektyvy rozvytku elektromobil'nogo transportu v Ukrai'ni», Naukova dumka, mat-ly Mizhn. nauk.-prakt. konferencii', vid 19 cherv., Vol. 4, Odesa, pp. 50-54.

3. Girin, V.S. and Girin, I.V. (2017), «Suchasnyj stan elektromobil'nogo transportu ta jogo perspektyvy v Ukrai'ni», Girnychyj visnyk, Vol. 102, pp. 21-26.

4. Groma, Ja.V. and Glushhenko, Ja.I., «Porivnjal'nyj analiz rynku elektromobiliv v Ukrai'ni ta sviti», [Online], available at: http://ev.fmm.kpi.ua/article/download/181408/181350 
5. «Z 1 lypnja vstupajut' u diju zminy v DBN, jaki zobov'jazujut' vlashtovuvaty na parkovkah minimum $5 \%$ misc' z elektrozarjadkamy», [Online], available at: https://www.kmu.gov.ua/news/z-1-lipnya-vstupayut-v-diyu-zmini-vdbn-yaki-zobovyazuyut-vlashtovuvati-na-parkovkah-minimum-5-misc-z-elektrozaryadkami

6. Kotenko, O.O., Domashenko, M.D. and Serdjuk, S.V. (2019), «Energoefektyvni avtomobili ta i'h rol' v antykryzovij strategii' pidpryjemstv Ukrai'ny», Oblik i finansy, No. 1 (83), pp. 152-158.

7. Kuzhel', V.P. and Harchuk, O.V. (2016), «Problemy ta perspektyvy ekspluatacii' elektromobiliv na terytorii' Ukrai'ny», Zbirnyk naukovyh prac' naukovo-tehnichnoi' konferencii' Vinnyc'kogo nacional'nogo tehnichnogo universytet (fak.-t mash.-bud. ta trans.), vid 10-11 bereznja, Vinnyc'kyj nacional'nyj tehnichnyj universytet.

8. Nacional'nyj bank Ukrai'ny (2019), «Oficijnyj kurs gryvni shhodo inozemnyh valjut na 27.09.2019», [Online], available at: https://bank.gov.ua/markets/exchangerates?date $=27.09 .2019 \&$ period=daily

9. «Palyvo Jevro 5», [Online], available at: https://www.okko.ua/ru/fuels

10. Verhovna Rada Ukrai'ny (2019), «Podatkovyj kodeks Ukrai'ny», dokument, No. 2755-VI, red. vid 20 zhovtnja, [Online], available at: https://zakon.rada.gov.ua/laws/show/2755-17

11. «Taryfy na elektroenergiju, sho vidpuskajet'sja naselennju», [Online], available at: https://www.nerc.gov.ua/?id=15013

12. «Ukrai'ns'kyj rynok elektromobiliv nabyraje obertiv, v trendi - sekond-hend», [Online], available at: http://ukrautoprom.com.ua/ukra\%d1\%97nskij-rinok-elektromobiliv-nabiraye-obertiv-v-trendi-sekond-xend

13. Shevchuk, O.I. (2016), «Perspektyvy ekspluatacii' ta konkurentna spromozhnist' elektromobiliv v Ukrai'ni», Naukovyj visnyk Hersons'kogo derzhavnogo universytetu, Vol. 21, Part 2, pp. 43-46.

14. «Nissan Leaf Specifications», [Online], available at: https://www.nissanusa.com/vehicles/electric-cars/leaf.html

Котенко Олександр Олександрович - кандидат економічних наук, старший викладач кафедри міжнародних економічних відносин Сумського державного університету.

Наукові інтереси:

- антикризове управління;

- менеджмент зовнішньоекономічної діяльності;

- інвестиційний менеджмент;

- інноваційний менеджмент.

Домашенко Марина Дмитрівна - доцент кафедри міжнародних економічних відносин Сумського державного університету.

Наукові інтереси:

- еколого-економічна безпека;

- міжнародні економічні відносини;

- енергоефективність та ресурсозбереження.

Сердюк Сергій Володимирович - експерт автомобільного ринку, старший консультант 3 продажу автомобілів ПрАТ «Суми-Авто» «Автоцентр на Харківській». 